\title{
Sifat Volumetrik Campuran Laston Menggunakan Aspal Modifikasi Getah Pinus dan Limbah Styrofoam
}

\author{
Volumetric Properties of Asphalt Concrete Using \\ Pine Resin and Waste Styrofoam Modified Asphalt
}

\author{
Ratna Yuniarti*, Hasyim, Rohani, Desi Widianty \\ Jurusan Teknik Sipil Fakultas Teknik Universitas Mataram, INDONESIA. Tel. +62-0370 636126 \\ *corresponding author, email: ratna_yuniarti@unram.ac.id
}

Manuscript received: 01-03-2021. Accepted: 18-05-2021

\begin{abstract}
ABSTRAK
Sifat volumetrik campuran pada laston merupakan salah satu faktor yang menentukan durabilitas (keawetan) lapis perkerasan jalan.Untuk meningkatkan keawetan lapis perkerasan jalan dan mengurangi dampak negatif terhadap lingkungan dapat dilakukan antara lain melalui modifikasi aspal dengan getah pinus dan limbah styrofoam. Tulisan ini bertujuan untuk mengkaji sifat volumetrik campuran laston menggunakan aspal modifikasi getah pinus dan limbah styrofoam tersebut. Sifat volumetrik campuran laston yang dikaji adalah rongga dalam campuran, rongga di antara mineral agregat, rongga terselimuti aspal, density dan bulk specific gravity. Pada penelitian ini digunakan agregat bergradasi rapat yang dicampur dengan aspal modifikasi pada suhu $155^{\circ} \mathrm{C}$ dan dipadatkan 75 kali pada kedua sisinya. Pada seluruh benda uji, prosentase limbah styrofoam yang digunakan adalah $6 \%$ sedangkan getah pinus sebesar $0 \%, 1 \%, 2 \%$ dan 3\% terhadap berat aspal modifikasi.Hasil penelitian menunjukkan bahwa campuran laston yang menggunakan aspal modifikasi getah pinus menghasilkan nilai VFB, density dan bulk specific gravity lebih besarserta nilai VIM dan VMA lebih kecil dibandingkan dengan campuran yang menggunakan aspal modifikasi limbah styrofoam.Dengan nilai VIM dan VMA lebih kecil, campuran yang menggunakan aspal modifikasi getah pinus menghasilkan daya ikat lebih kuat sehingga memiliki durabilitas lebih tinggi. Ditinjau dari persyaratan laston sebagai lapis aus pada perkerasan jalan, penggunaan getah pinus dan limbah styrofoam sebagai modifier aspal memenuhi persyaratan volumetrik campuran.
\end{abstract}

Kata kunci:aspal modifikasi; getah pinus; limbah styrofoam; laston

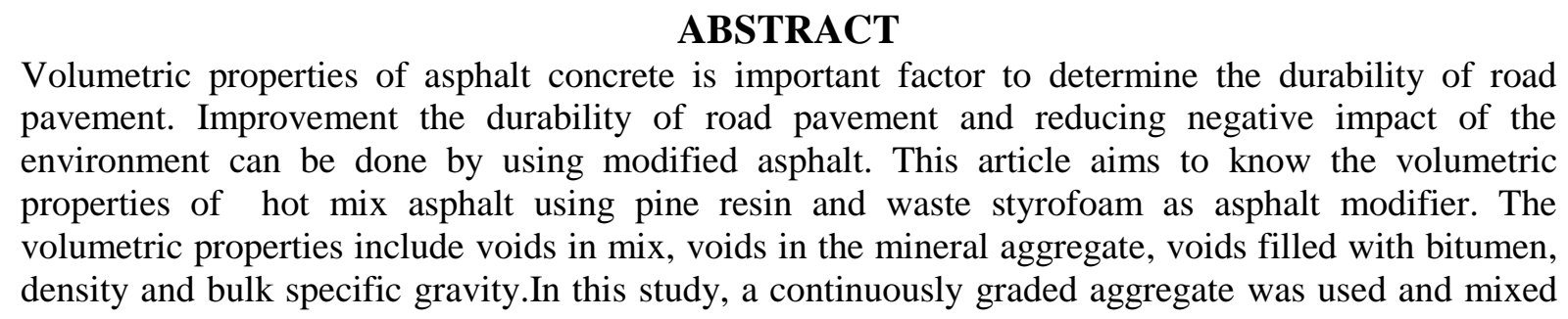


with modified asphalt at $155^{\circ} \mathrm{C}$ and compacted with 75 blows on both sides. The percentage of waste styrofoam was $6 \%$ whereas the percentages of pine resin where $0 \%, 1 \%, 2 \%$ and $3 \%$ by weight of modified asphalt. From the analysis, it can be concluded that asphalt concrete containing pine resin as modifier strengthen the binding between asphalt and agregate, due to increasing value of voids filled with bitumen (VFB), density and bulk specific gravity. Durability of asphalt concrete using pine resin as modifier was higher than that of asphalt concrete using waste styrofoam because of decreasingvalue of voids in mix (VIM) and voids in the mineral aggregate (VMA). Based on the specification of asphalt concrete wearing course, the use of pine resin and waste styrofoam as asphalt modifier has fulfilled volumetric properties requirements.

Key words:modified asphalt; pine resin; waste styrofoam; asphalt concrete

\section{PENDAHULUAN}

Upaya untuk mengatasi kerusakan jalan agar dapat berfungsi sesuai dengan umur yang telah direncanakan sebelumnya dapat dilakukan antara lain dengan meningkatkan kualitas bahan perkerasan jalan yang digunakan. Berbagai bahan limbah telah banyak diteliti sebagai modifier aspal untuk meningkatkan kinerja hot mix asphalt dan mengurangi dampak negatif dari limbah tersebut terhadap lingkungan (Mashuri, 2009;Asliet al., 2012; Yuniarti, 2013;Xinxinet al., 2018; Yuniarti dkk., 2018;Firmansyah, 2019; Rozy, 2019).

Salah satu jenis limbah yang sulit diuraikan dan memerlukan lahan luas untuk penanganannya adalah limbah styrofoam. Styrofoam yang biasanya digunakan sebagai pengganjal pada proses pengepakan barang-barang elektronik dan wadah makanan merupakan permasalahan yang menjadi beban pemerintah daerah terutama di kota-kota besar. Fitidarini dan Damanhuri (2011) menyebutkan bahwa limbah styrofoam yang ditimbun di Tempat Pembuangan Akhir (TPA) sampah Sarimukti Bandung diperkirakan berjumlah 20,185 ton/bulan. Kondisi ini berpotensi membuat TPA cepat mengalami over kapasitas. Di samping itu, Cordovadan Nurhati (2019) menyebutkan bahwa sekitar 8,32 ton/hari sampahplastik masuk ke Teluk Jakarta dan didominasi oleh limbah styrofoam.

Adapun bahan-bahan nabati seperti getah tumbuhan banyak diteliti sebagai modifier pada aspal karena karakteristiknya yang mirip dengan aspal konvensional (Huang et al., 2012). Getah pinus yang diperoleh dari hasil sadapan pohon Pinus merkusiimemiliki daya ikat yang kuat sehingga ketika digunakan sebagai modifier pada aspal menghasilkan campuran aspal porus yang lebih kuat menerima pembebanan dibandingkan dengan campuran yang menggunakan aspal konvensional (Yuniarti, 2019). Penggunaan getah pinus sebagai modifier pada aspal juga menghasilkan nilai indeks kekuatan sisa lebih besar yang berarti campuran tersebut lebih tahan terhadap rendaman air (Yuniarti dkk., 2021).

Laston merupakan lapis perkerasan jalan yang terdiri dari agregat bergradasi menerus dengan aspal sebagai bahan pengikatnya. Sifat volumetrik campuran pada laston merupakan faktor penting karena menentukan tingkat durabilitas (keawetan) campuran tersebut. Jika rongga dalam campuran terlalu besar, perkerasan jalan akan rentan terhadap kerusakan karena mudah terkena oksidasi matahari. Air juga mudah untuk meresap masuk dan mengisi rongga pori sehingga melepaskan ikatan antara aspal dan agregat yang berakibat pada terjadinya pengelupasan butiran dan berbagai macam kerusakan lapis perkerasan jalan. Sebaliknya bila rongga dalam campuran terlalu kecil, rongga tersebut tidak cukup untuk 
menampung kadar aspal akibat terjadinya pemadatan berulang oleh beban lalu lintas sehingga menimbulkan bleedingyaitu aspal meleleh keluar ke permukaan jalan terutama ketika meningkatnya temperatur perkerasan (Kandhal and Chakraborty, 1996).

Mengingat pentingnya sifat volumetrik campuran pada laston serta urgensi peningkatan kualitas aspal menggunakan getah pinus dan limbah styrofoam, tulisan ini bertujuan untuk mengkaji sifat volumetrik campuran tersebut. Sifat volumetrik dari campuran laston yang dikaji adalah rongga dalam campuran, rongga di antara mineral agregat, rongga terselimuti aspal, density dan bulk specific gravity.

\section{BAHAN DAN METODE}

Pada penelitian ini, digunakan aspal, getah pinus, limbah styrofoam, agregat kasar, agregat halus danabu batu sebagai bahan pengisi (filler). Agregat kasar, halus dan filler diambil dari Pringgabaya, Lombok Timur. Aspal yang dipakai adalah aspal grade 60/70 sedangkan getah pinus yang digunakan diambil dari hasil sadapan getah pinus di perkebunan rakyatdi Kabupaten Malang, Jawa Timur.Adapun limbah styrofoam berasal dari styrofoam bekas digunakan pada pengepakanbarang-barang elektronik.

Pemeriksaan sifat-sifat fisik agregat terdiri dari uji analisa saringan, keausan, berat jenis dan kelekatan agregat terhadap aspal. Pengujian analisa saringan mengikuti prosedur SNI 031968-1990, pengujian berat jenis agregat kasar sesuai dengan SNI 1969:2008, pengujian berat jenis agregat halus berdasarkan prosedur SNI 1970:2008, sedangkan pengujian kelekatan agregat terhadap aspal sesuai dengan SNI 03-2439-1991.

Aspal modifikasi dibuat dengan cara mencampurkan aspal penetrasi 60/70 dengan getah pinus dan limbah styrofoam. Sesuai dengan penelitian Putra (2019), prosentase styrofoam yang optimum sebagai modifier adalah $6 \%$ terhadap berat aspal modifikasi, sehingga pada seluruh specimen penelitian ini digunakan styrofoam sebesar 6\%. Aspal modifikasi yang diwakili oleh kode specimen berturut-turut AM0, AM1, AM2 dan AM3 memiliki prosentase aspal penetrasi 60/70 masing-masing sebesar 94\%, 93\%, 92\% dan 91\% sedangkan prosentase getah pinus adalah $0 \%, 1 \%, 2 \%$ dan $3 \%$ terhadap berat aspal modifikasi.

Adapun distribusi ukuran partikel agregat yang digunakan ditampilkan pada Gambar 1.

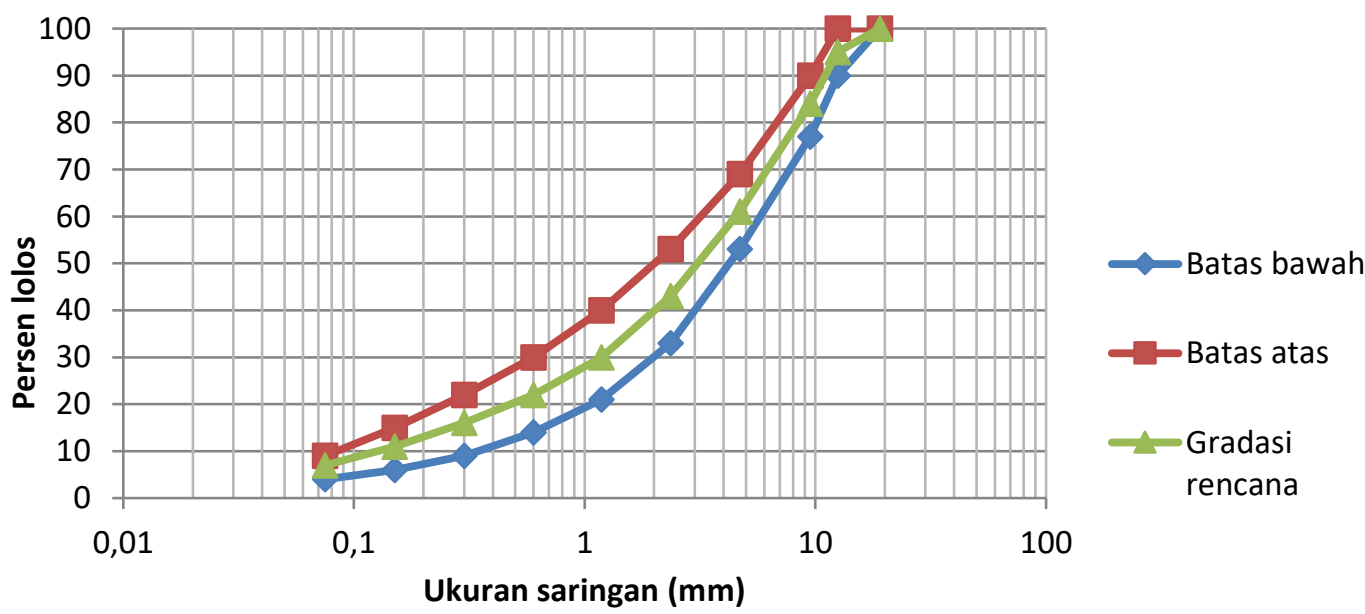

Gambar 1. Distribusi ukuran agregat yang digunakan 


\section{HASIL DAN PEMBAHASAN}

Tabel 1. Hasil pengujianagregat

\begin{tabular}{ccccc}
\hline Jenis pengujian & $\begin{array}{c}\text { Agregat } \\
\text { kasar }\end{array}$ & $\begin{array}{c}\text { Agregat } \\
\text { halus }\end{array}$ & Filler & Persyaratan*) \\
\hline Keausan impact $(\%)$ & 9.3 & - & - & Maks. 30 \\
Berat jenis bulk & 2.66 & 2.76 & 2.66 & Min. 2.5 \\
Berat jenis semu & 2.78 & 2.78 & 2.67 & Min. 2.5 \\
Penyerapan terhadap air $(\%)$ & 1.6 & 0.31 & 0.24 & Maks. 3 \\
Kelekatan agregat terhadap aspal (\%) & 100 & - & - & Min. 95 \\
\hline
\end{tabular}

Sumber: *) Direktorat Jenderal Bina Marga (2018)

Tabel 2. Hasil pengujian aspal 60/70 dan aspal modifikasi limbah styrofoam 6\%

\begin{tabular}{cccc}
\hline Jenispengujian & Hasil uji aspal 60/70 & $\begin{array}{c}\text { Hasil uji aspal } \\
\text { modifikasi limbah } \\
\text { styrofoam 6\% }\end{array}$ & $\begin{array}{c}\text { Persyaratan } \\
\text { aspal 60/70*) }\end{array}$ \\
\hline Penetrasi $(0.1 \mathrm{~mm})$ & 66.3 & 63.5 & $60-79$ \\
Titiklembek $\left({ }^{\circ} \mathrm{C}\right)$ & 48.9 & 52.5 & $>48$ \\
Titiknyala $\left({ }^{\circ} \mathrm{C}\right)$ & $>300$ & $>300$ & $>232$ \\
Daktilitas $(\mathrm{cm})$ & 137.8 & 48.8 & $>100$ \\
Beratjenis & 1.051 & 1.023 & $>1.0$ \\
Kehilangan berat $(\%)$ & 0.213 & 0.275 & $0.8 \%$ \\
\hline
\end{tabular}

Sumber: *) Direktorat Jenderal Bina Marga (2018)

Berdasarkan Tabel 1, agregat yang digunakan memenuhi persyaratan yang ditetapkan Direktorat Jenderal Bina Marga (2018). Nilai keausan impact 9.3\% yang jauh lebih kecil dari persyaratan maksimal 30\% menunjukkan bahwa agregat memiliki ketahanan yang baik terhadap beban yang diterima. Berat jenis bulk agregat yang memperhitungkan berat agregat dalam keadaan kering terhadap seluruh volume agregat menunjukkan nilai yang lebih besar dari persyaratan minimal 2.5. Adapun berat jenis semu yang diperoleh dari perhitungan berat agregat dalam keadaan kering dan volume agregat yang dapat diresapi air juga sesuai dengan persyaratan.Penyerapan air pada agregat yang kurang dari 3\% menunjukkan bahwa pori-pori dan absorpsi agregat cukup kecil sehingga air tidak mudah meresap masuk yang dapat mengakibatkan lepasnya ikatan antara aspal dan agregat. Adapun kelekatan agregat terhadap aspal sebesar $100 \%$ menunjukkan bahwa seluruh permukaan agregat dapat diselimuti aspal.

Berdasarkan Tabel 2, aspal penetrasi 60/70 yang digunakan pada penelitian ini menjadi lebih keras setelah dicampurkan dengan styrofoam. Hal tersebut ditunjukkan dengan perubahan nilai penetrasi dari $66.3 \mathrm{dmm}$ menjadi $63.5 \mathrm{dmm}$ dan titik lembek meningkat dari $48.9{ }^{\circ} \mathrm{C}$ menjadi $52.5{ }^{\circ} \mathrm{C}$. Meningkatnya modulus kekakuan aspal berarti bahwa aspal lebih tidak peka terhadap perubahan temperatur sehingga cocok untuk diaplikasikan pada negara yang beriklim panas seperti di Indonesia. Adapun tingkat kemuluran aspal menjadi berkurang dengan penambahan styrofoam $6 \%$ dari $137.8 \mathrm{~cm}$ menjadi $48.8 \mathrm{~cm}$. Menurut spesifikasi Direktorat Jenderal Bina Marga (2018), aspal penetrasi 60/70 dianggap mempunyai kelenturan yang baik bila nilai daktilitas lebih dari $100 \mathrm{~cm}$. Namun aspal superfleks dengan panjang daktilitas $20 \mathrm{~cm}$ yang diterapkan pada jalan tol Semanggi-Cawang mampu bertahan 
lebih dari 7 tahun tanpa rusak sehingga disarankan bahwa tes ini tidak perlu disyaratkan dalam spesifikasi (Soehartono, 2014).

Ditinjau dari nilai berat jenis, terlihat bahwa penggunaan limbah styrofoam sebagai modifier menurunkan berat jenis dari 1.051 menjadi 1.023 karenakarakteristik styrofoam yang ringan dan berkerapatan rendah (Saleh, dkk., 2014). Uji sifat fisik lainnya adalah kehilangan berat yang digunakan untuk mengetahui fraksi aspal yang mudah menguap akibat pemanasan melalui pengovenan selama 5 jam pada suhu $163{ }^{\circ} \mathrm{C}$. Berdasarkan Tabel 2, hasil uji kehilangan berat menunjukkan bahwa aspal tidak mudah rapuh dan tidak banyak unsur yang hilang ketika dipanaskan. Hasil uji titik nyala aspal yang lebih tinggi dari $300{ }^{\circ} \mathrm{C}$ menunjukkan bahwa aspal aman digunakan pada proses pencampuran secara panas (hot mix) pada suhu $155^{\circ} \mathrm{C}$.

Adapunnilai VIM, VMA, VFB, density dan bulk specific gravitypada campuran menggunakan aspal modifikasi styrofoam $6 \%$ serta getah pinus $0 \%, 1 \%, 2 \%$ dan $3 \%$ disajikan pada Gambar 2 sampai dengan Gambar 6sebagai berikut.

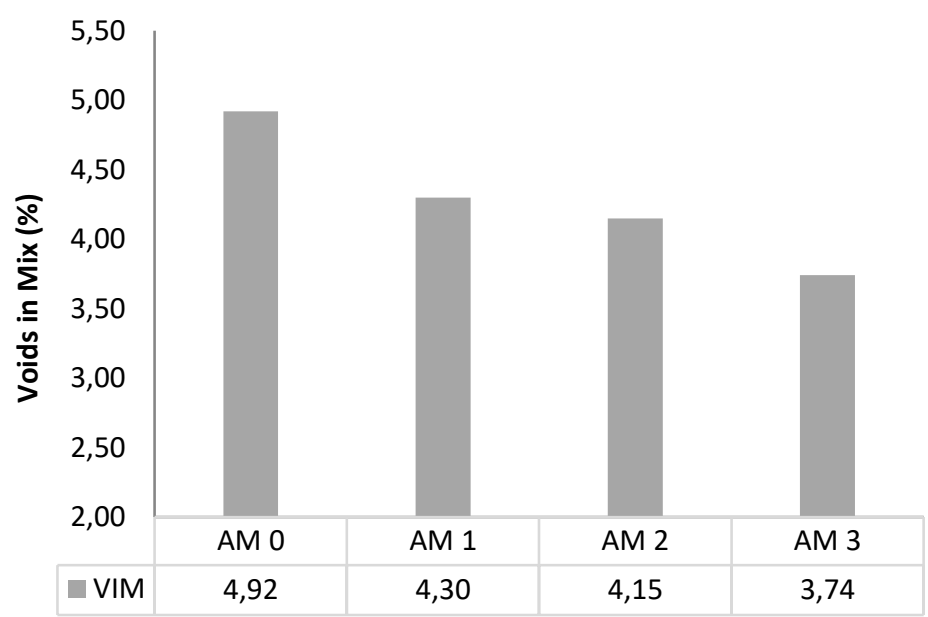

Gambar 2. Nilai Voids in Mix(VIM)

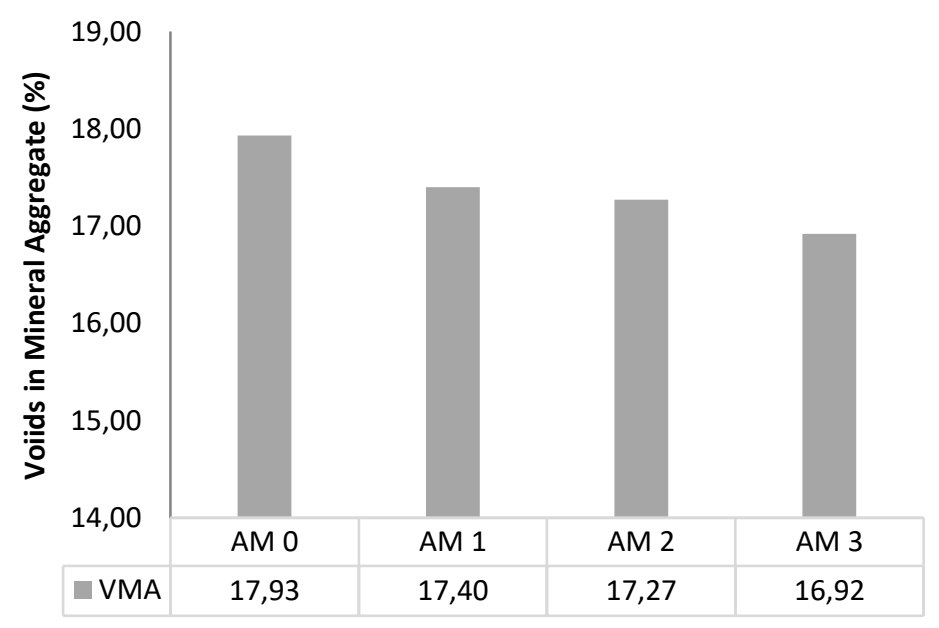

Gambar 3. Nilai Voids in Mineral Aggregate (VMA) 


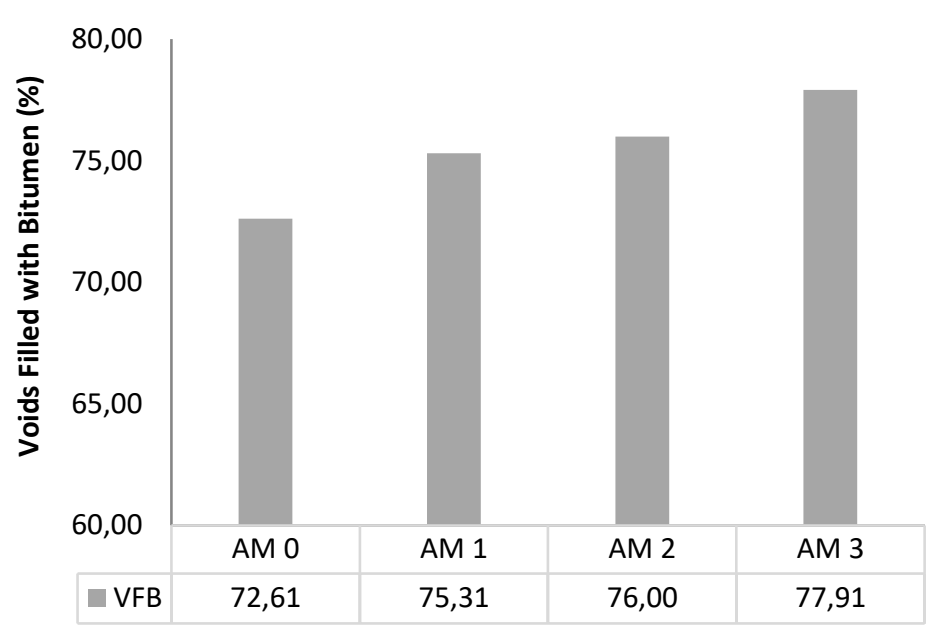

Gambar 4. Nilai Voids Filled with Bitumen (VFB)

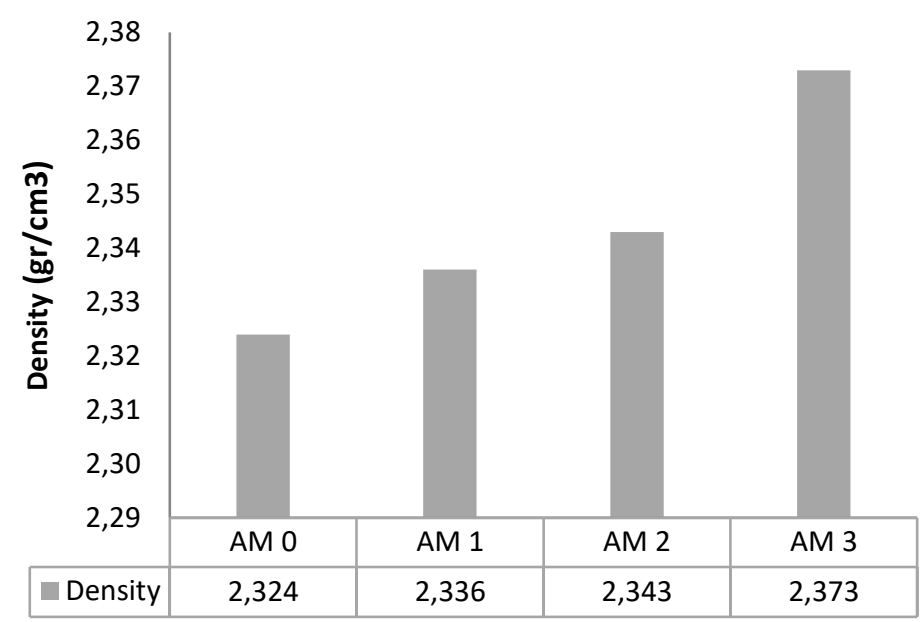

Gambar 5. Nilai density

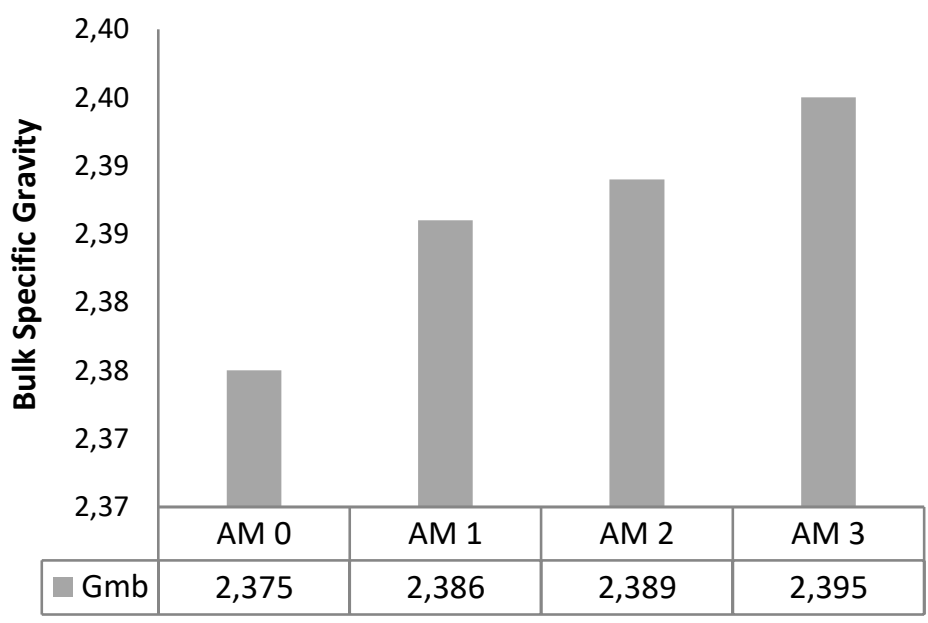

Gambar 6. Nilai bulk specific gravity 
Berdasarkan Gambar 2, nilai VIM semakin mengecil seiring dengan penambahan prosentase getah pinus pada aspal modifikasi. Sifat getah pinus yang lengket menghasilkan aspal modifikasi yang mengikat partikel-partikel agregat secara lebih kuat sehingga rongga yang terbentuk di dalam campuran menjadi lebih kecil. Hasil penelitian ini memperkuat kesimpulan Yuniarti (2015) bahwa penggunaan getah pinus sebagai modifier pada aspal menghasilkan rongga dalam campuran sedemikian rupa sehingga ikatan aspal-agregat tersebut mampu untuk menahan beban lalu lintas berat.

Gambar 3 menyajikan nilai VMAdi mana fenomena ini memiliki kecenderungan yang sama dengan Gambar 2. Nilai VMA semakin mengecil pada campuran yang menggunakan aspal modifikasi getah pinus dibandingkan dengan aspal yang ditambahkan limbah styrofoam saja. Dengan penambahan prosentase getah pinus, proses pemadatan yang dilakukan menghasilkan lekatan yang lebih baik sehingga jarak antara partikel-partikel agregat lebih dekat. Hasil ini sejalan dengan penelitian sebelumnya bahwa semakin kuat ikatan antara aspal dan agregat, maka campuran yang dihasilkan semakin padat (Yuniarti, 2015). Padatnya campuran menyebabkan rongga yang terbentuk di antara mineral agregat menjadi semakin kecil. Dengan ikatan yang lebih kuat, pengelupasan aspal dari agregat akan lebih bisa diminimalisir sehingga lapis perkerasan lebih awet.

Adapun nilai VFB pada campuran yang menggunakan aspal modifikasi limbah styrofoam dan getah pinus disajikan pada Gambar 4. VFB adalah prosentase rongga yang terselimuti aspal dalam VMA. Campuran yang menggunakan aspal modifikasi getah pinus menghasilkan nilai VFB yang lebih besar dibandingkan dengan campuran yang menggunakan aspal modifikasi limbah styrofoam saja. Semakin besar rongga yang terisi aspal, maka selimut aspal makin tebal sehingga ikatan antara partikel agregat lebih kuat.Hal tersebut juga sesuai dengan Gogula,et al.(2004) bahwa semakin besar nilai VFB, keawetan campuran lebih baik karena lebih tahan terhadap rendaman air.

Pada Gambar 5 disajikan nilai density (kepadatan) dari campuran. Kepadatan campuran yang menggunakan aspal modifikasi limbah styrofoam tanpa getah pinus sebesar $2.324 \mathrm{gr} / \mathrm{cm}^{3}$ sedangkan dengan prosentase getah pinus $1 \%, 2 \%$ dan $3 \%$ berturut-turut sebesar $2.336 \mathrm{gr} / \mathrm{cm}^{3}, 2.343 \mathrm{gr} / \mathrm{cm}^{3}$ dan $2.373 \mathrm{gr} / \mathrm{cm}^{3}$. Campuran dengan prosentase getah pinus lebih banyak menghasilkan kepadatan yang lebih tinggi. Dengan daya ikat antara partikel-partikel agregat lebih besar, kemampuan untuk memikul beban juga lebih tinggi. Sebagaimana yang disajikan pada Gambar 5 dan Gambar 2, nilai density yang dihasilkan pada seluruh campuran menggunakan aspal modifikasi getah pinus dan limbah styrofoam berbanding terbalik dengan nilai VIM. Semakin padat campuran yang terbentuk, maka rongga dalam campuran semakin kecil (Yuniarti dkk., 2018).

Gambar 6 menyajikan nilai bulk specific gravity dari campuran yang diperoleh dari berat kering campuran yang sudah dipadatkan dibagi dengan volume bulk dari campuran tersebut. Nilai bulk specific gravity dari campuran yang menggunakan aspal modifikasi limbah styrofoam adalah 2.375 sedangkan pada campuran yang menggunakan prosentase getah pinus $1 \%, 2 \%$ dan 3\%, berada pada rentang 2.386-2.395. Nilai bulk specific gravityyang semakin besar mengindikasikan bahwa ikatan yang dihasilkan dari penggunaan 
getah pinus semakin kuat sehingga campuran tersebut lebih tahan terhadap berbagai jenis kerusakan.

Ditinjau dari persyaratan laston sebagai lapis aus pada perkerasan jalan yaitu nilai VIM pada rentang 3.5\%-5.5\%, nilai VMA minimal 15\% dan VFB minimal 65\%, campuran menggunakan aspal modifikasi getah pinus dan limbah styrofoam pada penelitian ini memenuhi spesifikasi yang berlaku.

\section{KESIMPULAN}

Dari pembahasan yang telah dilakukan, dapat ditarik kesimpulan bahwa campuran laston menggunakan aspal modifikasi getah pinus menghasilkan nilai VFB, density dan bulk specific gravity yang lebih besar dibandingkan dengan campuran menggunakan aspal modifikasi limbah styrofoam saja. Penambahan prosentase getah pinus pada aspal modifikasi memperkecil nilai VIM dan VMA menunjukkan daya ikat yang lebih kuat antara aspal dan agregat. Pada campuran yang menggunakan aspal modifikasi getah pinus,prosentase ronggaterselimuti aspal semakin besar sehingga menghasilkan durabilitas (keawetan) lebih tinggi dibandingkan dengan campuran yang menggunakan aspal modifikasi limbah styrofoam saja. Ditinjau dari persyaratan laston sebagai lapis aus pada perkerasan jalan, campuran laston menggunakan aspal modifikasi getah pinus dan limbah styrofoammemenuhi persyaratan nilai rongga dalam campuran (VIM), rongga di antara mineral agregat (VMA) dan rongga yang terisi aspal (VFB).

\section{UcapanTerimakasih}

Ucapan terima kasih disampaikan kepada Rektor Universitas Mataram yang telah membiayai penelitian ini dengan dana yang bersumber dari DIPA BLU (PNBP) Tahun Anggaran 2020.

\section{DAFTAR PUSTAKA}

Asli, H.; Ahmadinia, E.; Zargar, M.; Karim, M.R., 2012. Investigation on Physical Properties of Waste Cooking Oil-Rejuvenated Bitumen Binder, Construction and Building Materials, 37:398-405.

Cordova, M.R. dan Nurhati, I.S., 2019. Major Sources and Monthly Variations in the Release of Land-Derived Marine Debris from the Greater Jakarta Area, Indonesia, Scientific Reports 9:18730| https://doi.org/10.1038/s41598-019-55065-2.

Direktorat Jenderal Bina Marga, 2018. Spesifikasi Umum 2018 Untuk Pekerjaan Konstruksi Jalan dan Jembatan, Jakarta.

Firmansyah, H., 2019. Pengaruh Penggunaan Plastik LLDPE (Low Liniear Density Polyethylene) Terhadap Kinerja Campuran Asphalt Concrete-Wearing Course,Tugas Akhir, Jurusan Teknik Sipil Fakultas Teknik Universitas Mataram.

Fitidarini, N. L. dan Damanhuri, E., 2011. Timbulan Sampah Styrofoam Di Kota Bandung, Jurnal Teknik Lingkungan, 17(2):87-97. 
Gogula, A.K.; Hossain, M.; Romanoschi, S.A., 2004. A Study of Factors Affecting the Permeability of Superpave Mixes in Kansas, Kansas State University, Manhattan, Kansas.

Huang, S. C.; Salomon, D. and Haddock, J. E., 2012.Work-shop Introduction, Transportation Research Circular E-C165, Transportation Research Board, Washington, D.C.

Kandhal, P. and Chakraborty, S., 1996. Evaluation of Voids in the Mineral Aggregatefor HMA Paving Mixtures, National Center for Asphalt Technology Auburn University, Alabama.

Mashuri, 2009.Karakteristik Aspal Sebagai Bahan Pengikat yang Ditambahkan Plastik Polyvinyl Chloride (PVC), Majalah Ilmiah Mektek, 11 (2): 117-124.

Putra, A., 2019. Pengaruh Penggunaan Styrofoam Terhadap Kinerja Campuran Aspal Beton (AC-WC),Tugas Akhir, Jurusan Teknik Sipil Fakultas Teknik Universitas Mataram.

Rozy, F., 2019.Pengaruh Penggunaan Plastik PVC Terhadap Kinerja Campuran Aspal Beton (AC-WC), Tugas Akhir, Jurusan Teknik Sipil Fakultas Teknik Universitas Mataram.

Saleh, S.M.; Anggraini, R.; Aquina, H., 2014. Karakteristik Campuran Aspal Porus dengan Substitusi Styrofoam Pada Aspal Pen 60/70, Jurnal Teknik Sipil ITB, 21(3): 241-250.

Soehartono, 2014. Teknologi Aspal dan Penggunaan dalam Konstruksi Perkerasan Jalan. Andi. Yogyakarta.

Xinxin, C.; Xuejuan, C.; Boming, T.; Yuanyuan, W.; Xiaolong, L., 2018. Investigation on Possibility of Waste Vegetable Oil Rejuvenating Aged Asphalt, Appl. Sci., 8:765.

Yuniarti, R., 2013. Pemanfaatan Limbah Minyak Goreng Sebagai Bahan Peremaja Aspal Lama, Jurnal Penelitian Universitas Mataram, 17(1): 84-93.

Yuniarti, R., 2015. Performance of Bio-Flux Oil as Modifier of Buton Granular Asphalt in Asphalt Concrete-Wearing Course, Journal of JSCE (Japan Society of Civil Engineers), 3(1): 33-44.

Yuniarti, R.; Hasyim; Rohani; Anwar, S.N.R.; Saptaningtyas, R. S., 2018. Karakteristik Campuran Asphalt Concrete Wearing Course Menggunakan Aspal Modifikasi Getah Pinus dan Serbuk Limbah Kaca, Prosiding Seminar Nasional Saintek, LPPM Universitas Mataram: 474-485.

Yuniarti, R., 2019. Resistance to Degradation of Porous Asphalt Mixture Using Pine Resinas Asphalt Modifier, Jordan Journal of Civil Engineering, 13(1): 113-123.

Yuniarti, R.; Hasyim; Rohani; Widianty, D., 2021. Pengaruh Daktilitas Aspal Modifikasi Getah Pinus dan Limbah Styrofoam Terhadap Karakteristik Campuran Aspal Beton, Prosiding SAINTEK,LPPM Universitas Mataram:112-121. 